\title{
PENGARUH NAUNGAN DAN ASAL BENIH TERHADAP DAYA HIDUP DAN PERTUMBUHAN ULIN (Eusideroxylon zwagery T. et B.)
}

\author{
The Effect of Shading and Seed Source on Survival and Growth of Ulin \\ (Eusideroxylon zwagery T. et B.) \\ Agung W. Nugroho, Junaidah, Fatahul Azwar dan/and Joni Muara \\ Balai Penelitian Kehutanan Palembang \\ Jl. Kol. H. Bastian Km 6,5 Kotak Pos 179, Puntikayu, Palembang \\ Telp./Fax. (0711) 414864
}

Naskah masuk : 1 November 2010; Naskah diterima : 26 Oktober 2011

\begin{abstract}
Ulin (Eusideroxylon zwagery T. et B.) is categorized as endangered species and included in semi tolerant species. Information of optimal light intensity (or light shading) is needed for ex-situ conservation program. The objective of this research was to investigate the effect of shading intensity and seed source on the survival and growth of ulin. This research was carried out at PT. Musi Hutan Persada, Suban Jeriji Village, Muara Enim Regency, South Sumatera. Research used split plot design with Acacia mangium age as main plot and seed population as sub plot. There are six levels of age of A. mangium such as 1, 2, 3, 4, 5, and 6 years. While seed source consist three regions, namely: Jangga Baru-Jambi; Beliti Jaya-South Sumatera and Gunung Serumput-Bangka Belitung. The results showed that shading intensity $81.05 \%$ and $86.15 \%$ increased significantly the survival of seedlings at average of $54.33 \%$ and $39.68 \%$ respectively. Seed source from Bangka Belitung was able to increase significant height growth of seedlings at average of $47.47 \mathrm{~cm}$ respectively.
\end{abstract}

Key words: Ulin, light intensity, seed source, survival rate, growth

\begin{abstract}
ABSTRAK
Ulin (Eusideroxylon zwagery T. et B.) termasuk jenis tanaman yang hampir punah dan bersifat semi toleran. Informasi intensitas cahaya (naungan) yang optimal sangat diperlukan untuk keberhasilan konservasi eks-situ jenis ini. Tujuan penelitian ini adalah untuk menguji pengaruh naungan dan asal sumber benih terhadap daya hidup dan pertumbuhan ulin umur 1 tahun. Penelitian dilaksanakan di bawah tegakan Acacia mangium berbagai umur PT Musi Hutan Persada Wilayah I Desa Suban Jeriji Blok Sodong Selatan Kecamatan Rambang Dangko Kabupaten Muara Enim Sumatera Selatan. Penelitian ini menggunakan rancangan petak terbagi dengan umur Acacia mangium sebagai petak utama dan asal benih sebagai sub plot. Umur Acacia mangium terdiri dari 6 taraf yaitu umur 1, 2, 3, 4, 5, dan 6 tahun. Asal benih berasal dari 3 daerah yaitu Jangga Baru-Jambi, Beliti Jaya-Sumatera Selatan dan Gunung SerumputBangka Belitung. Hasil penelitian menunjukkan intensitas naungan sebesar 81,05\% dan 86,15\% meningkatkan daya hidup ulin sebesar 54,33\% dan 39,68\%. Asal benih Bangka-Belitung meningkatkan pertumbuhan tinggi sebesar $47,47 \mathrm{~cm}$.
\end{abstract}

Kata kunci: Ulin, intensitas naungan, sumber benih, daya hidup, pertumbuhan

\section{PENDAHULUAN}

Kerusakan hutan alam di Indonesia semakin lama semakin meningkat semenjak pengelolaannya dilakukan oleh perusahaan Hak Pengusahaan Hutan yang melakukan pene- bangan hutan tanpa mengikuti acuan sistem silvikultur Tebang Pilih Indonesia (TPI). Kerusakan hutan yang terjadi pada tahun 1970-an diperhitungkan kerusakan hutan hanya 0,3 juta hektar setiap tahun, tahun 1980-an meningkat menjadi 0,6 juta hektar per tahun dan selanjutnya 
menjadi 0,9 juta hektar per tahun pada tahun 1990-an, sampai mencapai lebih dari 2 juta hektar per tahun (Hendromono, 2003 dalam Nugroho et al., 2006). Data terakhir menyebutkan bahwa laju deforestasi hutan sudah mencapai 2,83 juta hektar per tahun selama periode 1997-2000 dan kemudian turun menjadi 1,08 juta hektar per tahun untuk periode 2000-2005 (Badan Planologi Kehutanan, 2007). Degradasi hutan ini tidak diimbangi dengan peningkatan upaya untuk merehabilitasi hutan, yaitu hanya 1 juta hektar per tahun saja. Tingginya kerusakan hutan mengakibatkan hutan tidak lagi dapat berfungsi sebagai pengatur keseimbangan tata air, pencegah pencemaran udara dan air, penyimpan karbon, penghasil kayu dan non kayu, dan sebagai sumber keragaman genetik.

Salah satu jenis yang hampir punah akibat dari penebangan tidak terkendali dan perladangan berpindah adalah jenis ulin (Eusideroxylon zwageri $\mathrm{T}$. et B.) (Soerianegra dan Lemmens, 1993; IUCN, 2000). Populasi ulin di Jambi diperkirakan tinggal $15 \%$, populasi tersebut sebagian dalam bentuk kayu bekas tebangan dengan ketinggian 1-1,5 $\mathrm{m}$ dan berdiameter rata-rata lebih dari $1 \mathrm{~m}$ (Erwandi, 2007). Diperkirakan sekitar 30\% dari luas Tahura Sultan Thaha Syaifudin merupakan tempat hidup kayu ulin dan saat ini kondisinya sudah hancur akibat pembalakan liar, perambahan, dan okupasi (Abidin, 2006). Tegakan ulin dengan diameter lebih dari $60 \mathrm{~cm}$ sudah sulit ditemukan, pada umumnya hanya pohon kecil, tunas dari tunggul bekas tebangan 20-30 tahun lalu yang saat ini sudah semakin membesar (Nurdin, 2003). Berdasarkan data IUCN (2000), ulin telah dimasukkan dalam kategori vulnerable (VU Alcd $+2 c d)$ dan telah dievaluasi untuk dimasukkan dalam Appendix II CITES berdasarkan kondisi adanya perdagangan lokal dan ekspor. Melihat kondisi tersebut, upaya konservasi in-situ dan ex-situ harus segera dilakukan. Keberhasilan konservasi terutama secara ex-situ diantaranya didukung dengan teknik silvikultur yang tepat di lapangan.

Penanaman ulin di luar sebaran alaminya mengalami beberapa kendala diantaranya sifat ulin yang semi toleran artinya ulin pada umur muda peka terhadap intensitas cahaya yang tinggi, tetapi sejalan dengan pertumbuhannya pada tingkat dewasa jenis ini akan membutuhkan intensitas cahaya yang memadai (Masano dan Omon, 1983). Selain intensitas cahaya, penggunaan benih yang bermutu merupakan salah satu faktor yang mendukung keberhasilan penanaman. Benih yang bermutu ditentukan oleh kondisi benih dan asal benih. Asal benih berhubungan dengan faktor genetik dan karakteristik tempat tumbuh populasi benih. Atas dasar pertimbangan tersebut, maka dilakukan penelitian penanaman ulin dari 3 (tiga) asal benih di Sumatera dengan ditanam di berbagai umur tegakan Acacia mangium sebagai tanaman penaung. Penelitian ini bertujuan untuk mengetahui pengaruh intensitas naungan dan asal benih terhadap daya hidup dan pertumbuhan tanaman ulin umur 1 tahun di luar sebaran alaminya.

\section{METODOLOGI}

\section{A. Lokasi Penelitian}

Penelitian dilakukan di PT. Musi Hutan Persada Wilayah I Desa Suban Jeriji Blok Sodong Selatan Kecamatan Rambang Dangko Kabupaten Muara Enim. Lokasi penanaman secara geografis terletak pada $103^{\circ} 10^{\prime}-104^{\circ} 25^{\prime} \mathrm{BT}$ dan $3^{\circ} 05^{\prime}-5^{\circ} 28^{\prime}$ LS dengan ketinggian 60-200 m dpl., suhu rata-rata $29^{\circ} \mathrm{C}\left(22-33^{\circ} \mathrm{C}\right)$, curah hujan tahunan 1.890-3.330 mm dengan musim hujan bulan Oktober sampai dengan Mei dan musim kemarau bulan Juni sampai dengan September dengan kelerengan 0 - 8\%.

\section{B. Bahan dan Alat}

Bahan yang digunakan adalah tanaman ulin umur 1 tahun dari 3 (tiga) asal benih (Jambi, Sumatera Selatan, dan Bangka-Belitung), dan alat yang digunakan adalah GPS (Global Positioning System), luxmeter, kaliper, meteran, tallysheet.

\section{Metode Penelitian}

\section{Tahapan Penelitian}

\section{a. Eksplorasi sumber benih}

Eksplorasi dilakukan untuk mendapatkan materi benih dari 3 (tiga) asal populasi ulin di Sumatera. Pengambilan benih dilakukan secara acak yang mewakili kondisi populasi tegakan ulin. Benih dikumpulkan dari lantai hutan dan diambil yang kondisinya masih bagus (biji utuh). Benih dari masing-masing populasi dikumpulkan dan dicampur secara acak (bulking) kemudian dipisahkan sesuai dengan asal populasi. Deskripsi asal benih disajikan dalam Tabel 1 . 
Tabel (Table) 1. Asal benih (Seed source)

\begin{tabular}{|c|c|c|c|c|}
\hline $\begin{array}{c}\text { Asal benih } \\
\text { (Seed Source) }\end{array}$ & $\begin{array}{c}\text { Garis lintang } \\
\text { (Latitude) }\end{array}$ & $\begin{array}{l}\text { Garis bujur } \\
\text { (Longitude) }\end{array}$ & $\begin{array}{c}\text { Ketinggian } \\
\text { (Altitude) } \\
\text { (m dpl.) } \\
\text { (m asl.) }\end{array}$ & $\begin{array}{l}\text { Kelas sumber benih } \\
\text { (Class of seed source) }\end{array}$ \\
\hline $\begin{array}{l}\text { Hutan Lindung } \\
\text { Gunung Serumput } \\
\text { (Bangka -Belitung) }\end{array}$ & $03^{\circ} 00^{\prime} 39^{\prime \prime} \mathrm{LS}$ & $108^{\circ} 00^{\prime} 37^{\prime \prime} \mathrm{BT}$ & $50-89$ & $\begin{array}{l}\text { Belum teridentifikasi } \\
\text { (unidentified) }\end{array}$ \\
\hline $\begin{array}{l}\text { Cagar Alam Durian } \\
\text { Luncuk II, Ds. } \\
\text { Jangga Baru (Jambi) }\end{array}$ & $01^{\circ} 55^{\prime} 211^{\prime \prime L S}$ & $103^{\circ} 07^{\prime} 17^{\prime \prime} \mathrm{BT}$ & $48-53$ & $\begin{array}{l}\text { Belum teridentifikasi } \\
\text { (unidentified) }\end{array}$ \\
\hline $\begin{array}{l}\text { Hutan Adat } \\
\text { Mambang, } \\
\text { Ds. Beliti Jaya } \\
\text { (Sumatera Selatan) }\end{array}$ & $02^{\circ} 58^{\prime} 07$ " LS & $103^{0} 10^{\prime} 21^{\prime \prime} \mathrm{BT}$ & $46.9-71.8$ & $\begin{array}{l}\text { Soekarno-Hatta/ } \\
\text { Tegakan Benih } \\
\text { Teridentifikasi } \\
\text { (identified seed stand) } \\
\text { No. Sertifikat: } \\
\text { 38/V/BPTH.Sum - } \\
\text { 3/SSB/2006. }\end{array}$ \\
\hline
\end{tabular}

\section{b. Penyediaan bibit}

Benih hasil ekplorasi dikecambahkan di persemaian. Perlakuan pendahuluan adalah skarifikasi yaitu biji direndam dalam air selama \pm 4 jam, kemudian dijemur di bawah sinar matahari $( \pm 2$ jam) sampai kulit biji pecah dengan sendirinya. Setelah itu biji dikecambahkan di bedeng tabur dengan media pasir yang disterilkan dan disungkup. Penyapihan dilakukan terhadap kecambah yang sudah mempunyai 4-6 helai daun. Media sapih yang digunakan adalah topsoil dan ditempatkan dalam polybag ukuran $20 \mathrm{x}$ $25 \mathrm{~cm}$. Bibit siap tanam adalah bibit yang telah berumur 4 bulan. Rata-rata tinggi dan diameter bibit ulin umur 4 bulan dari berbagai asal benih disajikan pada Tabel 2 .

Tabel (Table) 2. Rata-rata tinggi $(\mathrm{cm})$ dan diameter $(\mathrm{mm})$ bibit ulin umur 4 bulan di persemaian (Average of height ( $\mathrm{cm}$ ) and diameter ( $\mathrm{mm}$ ) of 4 months old ulin seedlings at nursery)

\begin{tabular}{|c|l|c|c|c|}
\hline No. & \multicolumn{1}{|c|}{$\begin{array}{c}\text { Asal benih } \\
\text { (Seed source) }\end{array}$} & $\begin{array}{c}\text { Jumlah sampel } \\
\text { (Number of } \\
\text { sample) }\end{array}$ & $\begin{array}{c}\text { Rata-rata tinggi } \\
\text { (Mean of height) } \\
(\mathrm{cm})\end{array}$ & $\begin{array}{c}\text { Rata-rata diameter } \\
\text { (Mean of } \\
\text { diameter) }(\mathrm{mm})\end{array}$ \\
\hline 1 & $\begin{array}{l}\text { Gunung Serumput (Bangka - } \\
\text { Belitung) }\end{array}$ & 36 & $39,00 \pm 9,12$ & $5,59 \pm 1,16$ \\
\hline 2 & $\begin{array}{l}\text { Hutan Mambang (Beliti Jaya - } \\
\text { Sumatera Selatan) }\end{array}$ & 36 & $35,26 \pm 11,01$ & $5,42 \pm 1,49$ \\
\hline 3 & $\begin{array}{l}\text { Durian Luncuk II (Jangga } \\
\text { Baru-Jambi) }\end{array}$ & 36 & $34,17 \pm 7,79$ & $5,80 \pm 0,94$ \\
\hline & Rata-rata (Average) & $36,14 \pm 9,54$ & $5,60 \pm 1,21$ \\
\hline
\end{tabular}

\section{c. Penanaman dan Pemeliharaan}

Ulin ditanam di bawah tegakan $A$. mangium (sebagai naungan) pada berbagai umur dengan jarak tanam 9 × 3 m. Umur A. mangium digunakan sebagai pembeda besarnya tingkat naungan (\%) pada lantai hutan (Tabel3). 
Tabel (Table) 3. Intensitas cahaya di tegakan A. mangium pada umur yang berbeda selama 1 tahun (light intensity at diferent age of A. mangium during 1 year old after planting)

\begin{tabular}{|c|c|c|c|c|}
\hline \multirow{2}{*}{$\begin{array}{c}\text { Umur A. mangium (Age } \\
\text { of A. mangium) }\end{array}$} & \multicolumn{2}{|c|}{$\begin{array}{c}\text { Intensitas cahaya } \\
\text { (Light intensity) (\%) }\end{array}$} & \multicolumn{2}{c|}{$\begin{array}{c}\text { Intensitas naungan } \\
\text { (Shading intensity) }\end{array}$} \\
\cline { 2 - 5 } & Awal (Start) & Akhir (Finish) & Awal ( Start) & Akhir (Finish) \\
\hline 1 tahun & 55,1 & 10,06 & 44,9 & 89,94 \\
2 tahun & 27,37 & 2,22 & 72,63 & 97,78 \\
3 tahun & 23,5 & 11,96 & 76,5 & 88,04 \\
4 tahun & 21,7 & 37,05 & 78,3 & 62,95 \\
5 tahun & 18,95 & 32,83 & 81,05 & 67,17 \\
6 tahun & 13,85 & 8,58 & 86,15 & 91,42 \\
\hline
\end{tabular}

Kegiatan pemeliharaan meliputi pembersihan gulma, pemupukan, penyiangan, pendangiran, dan pemeliharaan batas plot. Kegiatan pemeliharaan dilakukan 3 (tiga) kali dalam setahun yaitu bulan April, Agustus, dan Desember.

\section{Rancangan Percobaan}

Rancangan percobaan yang digunakan adalah Rancangan Petak Terbagi (Split Plot Design). Petak utama adalah umur tegakan $A$. mangium (faktor naungan) yang terdiri dari 6 taraf yaitu $A$. mangium umur 1,2 , 3, 4, 5, dan 6 tahun. Anak petak adalah perlakuan asal benih terdiri dari 3 taraf yaitu: Jangga Baru-Jambi, Beliti Jaya-Sumatera Selatan, dan Belitung Timur-Bangka Belitung. Masing-masing anak petak terdiri dari 3 ulangan dan setiap ulangan terdiri dari 10 individu. Model sidik ragam yang digunakan adalah (Mattjik dan Sumertajaya, 2002):

$$
\mathrm{Y}_{\mathrm{ijk}}=\mu+\alpha_{\mathrm{i}}+\delta_{\mathrm{ik}}+\beta_{\mathrm{j}}+(\alpha \beta)_{\mathrm{ij}}+\varepsilon_{\mathrm{ijk}}
$$

$$
\text { dimana: } \begin{aligned}
\mathrm{Y}_{\mathrm{ijk}} & \text { nilai pengamatan pada } \\
& \text { faktor A taraf ke-i, faktor B } \\
& \text { taraf ke-j dan ulangan } \mathrm{k} \\
\left(\mu, \alpha_{\mathrm{i}}, \beta_{\mathrm{j}}\right)= & \text { komponen aditifrataan } \\
= & \text { pengaruh utama faktor A } \\
& \quad \text { (umur } \text { A. Mangium) } \\
= & \text { pengaruh utama faktor B } \\
& (\text { asal benih) } \\
= & \text { interaksi dari faktor A dan } \\
& \text { faktor B } \\
= & \text { komponen acak dari petak } \\
& \text { utama } \\
= & \text { pengaruh acak dari anak } \\
\delta_{\mathrm{ik}} & \text { petak yang menyebar } \\
\varepsilon_{\mathrm{ijk}} & \text { normal }
\end{aligned}
$$

Pengamatan dilakukan terhadap daya hidup, tinggi tanaman, dan diameter tanaman. Tinggi tanaman diukur dari permukaan tanah sampai titik tumbuh teratas sedangkan pengamatan diameter batang dilakukan dengan alat kaliper setinggi $10 \mathrm{~cm}$ di atas permukaan tanah.

\section{Analisa Data}

Analisis data statistik yang digunakan adalah analisis varian untuk mengetahui pengaruh perlakuan yang diterapkan. Untuk data persentase daya hidup terlebih dahulu ditransformasikan ke dalam bentuk Arc. Sin $\sqrt{\%}$, karena merupakan data proporsi atau data persentase yang diturunkan dari nisbah jumlah data dan data berada dalam wilayah $0-100 \%$ (Mattjik dan Sumertajaya, 2002). Jika hasil analisis varian menunjukkan perbedaan nyata, akan dilanjutkan dengan uji lanjut dengan Uji Jarak Berganda Duncan(DMRT).

\section{HASIL DAN PEMBAHASAN}

\section{A. Hasil}

Hasil analisis varian terhadap variabel pertumbuhan dan daya hidup tanaman ulin umur satu tahun disajikan pada Tabel 4. Asal benih berpengaruh nyata terhadap peningkatan pertumbuhan tinggi, dan umur $A$. mangium berpengaruh nyata terhadap daya hidup ulin. 
Tabel (Table) 4. Analisis varian pertumbuhan tinggi, diameter dan daya hidup ulin umur 1 tahun di lapangan (Analysis of variance for height, diameter and survival rate of one year after planting)

\begin{tabular}{|c|c|c|c|c|c|c|}
\hline \multirow{2}{*}{$\begin{array}{c}\text { Sumber } \\
\text { keragaman } \\
\text { (Source of } \\
\text { variation) }\end{array}$} & \multicolumn{2}{|c|}{ Tinggi (height) } & \multicolumn{2}{|c|}{ Diameter (diameter) } & \multicolumn{2}{|c|}{$\begin{array}{c}\text { Daya hidup } \\
\text { (Survival rate) }(\%)\end{array}$} \\
\hline & $\begin{array}{l}\text { F Hitung } \\
\text { (F value) }\end{array}$ & $\begin{array}{c}\text { Probabilitas } \\
(P r>F)\end{array}$ & $\begin{array}{l}\text { F Hitung } \\
\text { (F value) }\end{array}$ & $\begin{array}{c}\text { Probabilitas } \\
(P r>F)\end{array}$ & $\begin{array}{l}\text { F Hitung } \\
(F \text { value })\end{array}$ & $\begin{array}{c}\text { Probabilitas } \\
\quad(P r>F)\end{array}$ \\
\hline $\begin{array}{l}\text { Umur } A \text {. } \\
\text { mangium (age of } \\
\text { A. mangium) }\end{array}$ & $1,38^{\mathrm{ns}}$ & 0,26 & $0,21^{\mathrm{ns}}$ & 0,95 & $9,09^{*}$ & $<0,00$ \\
\hline $\begin{array}{l}\text { Asal benih (Seed } \\
\text { source) }\end{array}$ & $3,48^{*}$ & 0,04 & $1,07^{\mathrm{ns}}$ & 0,35 & $0,65^{\mathrm{ns}}$ & 0,52 \\
\hline $\begin{array}{l}\text { Interaksi } \\
\text { (Interaction) }\end{array}$ & $0,81^{\mathrm{ns}}$ & 0,60 & $0,91^{\mathrm{ns}}$ & 0,52 & $0,77^{\mathrm{ns}}$ & 0,65 \\
\hline $\begin{array}{l}\text { Ulangan } \\
\text { (replication) }\end{array}$ & $1,41^{\mathrm{ns}}$ & 0,26 & $0,04^{\mathrm{ns}}$ & 0,96 & $1,65^{\mathrm{ns}}$ & 0,20 \\
\hline Galat (error) & & & & & & \\
\hline
\end{tabular}

Keterangan (Remarks): ns= tidak berbeda nyata (not significant), *= berbeda nyata pada tingkat kepercayaan 95\% (significantly different at level $95 \%)$

Umur A. mangium yang lebih tua relatif memberikan daya hidup yang lebih tinggi bagi pertumbuhan ulin. Ulin di bawah tanaman penaung $A$. mangium umur 5 tahun mempunyai daya hidup terbaik sebesar $54,33 \%$. Hasil ini tidak berbeda bila ulin ditanam di bawah tegakan
A. mangium umur 6 tahun dengan persen hidup sebesar 39,68\% (Gambar 1).

Berdasarkan Tabel 4 tersebut di atas, maka sampai ulin berumur 1 tahun, belum terlihat adanya interaksi antara besarnya tingkat penaungan dengan asal benih.

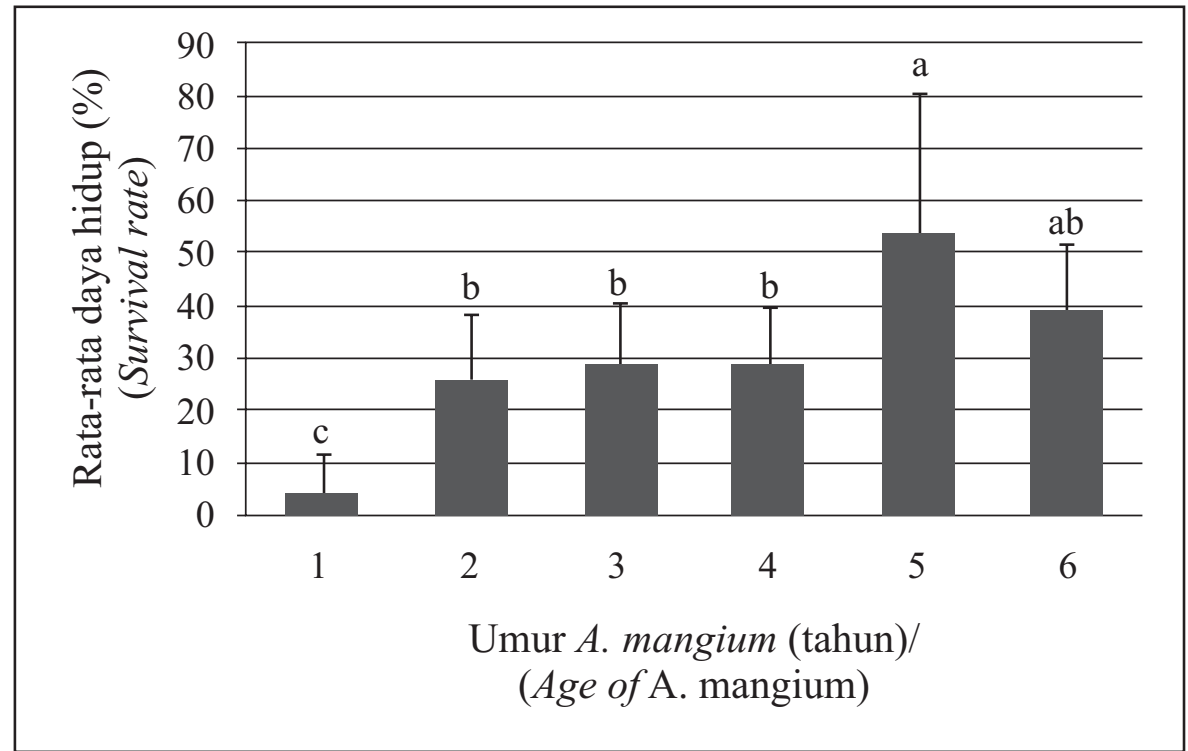

Gambar(Figure) 1. Hasil uji Duncan pengaruh umur A. mangium terhadap daya hidup (Duncan's test result on the influence of age of $\mathrm{A}$. mangium on seedling survival 1 year after planting) 
Perlakuan asal benih memberikan pengaruh nyata terhadap pertumbuhan tinggi dan berpengaruh tidak nyata terhadap pertumbuhan diameter dan daya hidup tanaman ulin. Hasil uji lanjut menunjukkan bahwa asal benih Belitung
Timur-Bangka Belitung memiliki pertumbuhan tinggi yang lebih baik sebesar $47,47 \mathrm{~cm}$ disusul asal benih Beliti Jaya-Sumatera Selatan dan Jangga Baru-Jambi (Gambar 2).

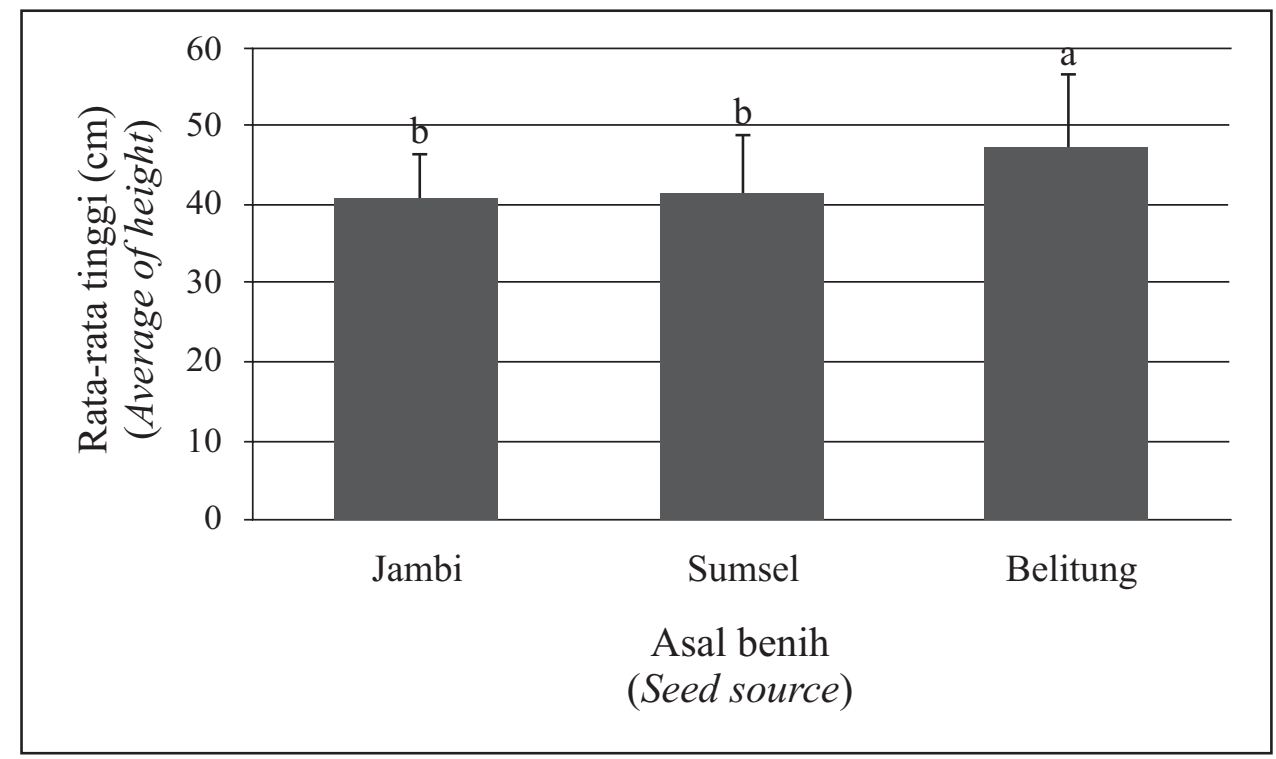

Gambar(Figure) 2. Hasil uji Duncan pengaruh asal benih terhadap tinggi (Duncan's test result on the influence of seed source to the height of seedling 1 year after planting)

Walaupun pertumbuhan diameter tanaman ulin pada berbagai perlakuan tidak berbeda nyata (Tabel 4), namun dapat terlihat bahwa diameter ulin pada tegakan umur $A$. mangium 4 dan 5 tahun, menunjukkan rata-rata diameter ulin yang paling baik sebesar $0,67 \mathrm{~cm}$ (Gambar 3).

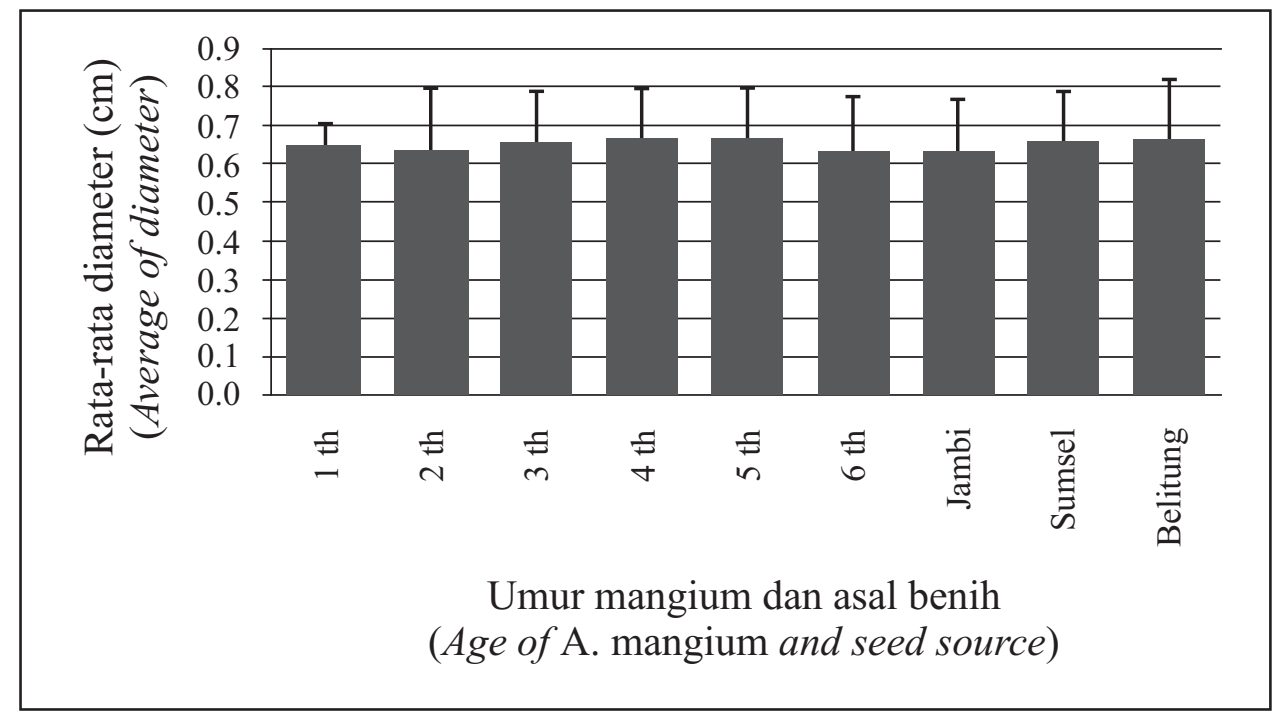

Gambar(Figure) 3. Pengaruh umur A. mangium dan asal benih terhadap rata-rata diameter (The inflluence of age of A. mangium and seed source to the diameter) 


\section{B. Pembahasan}

Dalam kondisi normal, pada tegakan $A$. mangium yang berumur lebih tua intensitas cahaya yang jatuh ke lantai hutan lebih rendah dibandingkan intensitas cahaya pada tegakan $A$. mangium yang lebih muda. Hasil pengamatan selama 1 tahun menunjukkan terjadi perbedaan dan perubahan intensitas cahaya yang jatuh pada lantai hutan di beberapa umur A. mangium. Kegiatan penebangan tegakan A. mangium pada tegakan $A$. mangium umur 4 dan 5 tahun karena telah memasuki masa daur tebang mengalami peningkatan intensitas cahaya di sekitar plot pengamatan, kondisi ini menyebabkan. intensitas cahaya yang masuk ke dalam tegakan tersebut pada akhir pengamatan lebih besar daripada awal pengamatan.

Hasil analisis keragaman menunjukkan pada tegakan A. mangium umur 5 tahun, ulin mempunyai daya hidup yang paling tinggi sebesar 54,33\%. Tegakan A. mangium umur 5 tahun dengan intensitas cahaya 18,95\% mampu memberikan kebutuhan cahaya yang cukup untuk pertumbuhan tanaman ulin di bawahnya. Cahaya optimum yang diterima ulin digunakan untuk proses fotosintesis dalam metabolisme. Selain itu, penutupan tajuk (naungan) yang cukup rapat memberikan pengaruh dalam menjaga kelembaban sehingga mampu meminimalkan stres lingkungan (suhu panas) yang dialami ulin pada awal penanaman.

Daya hidup yang paling rendah terdapat pada ulin di bawah tegakan $A$. mangium umur 1 tahun sebesar 4,3\%, intensitas cahaya yang masuk terlalu tinggi $(55,1 \%)$ untuk anakan ulin. Efisiensi pemanfaatan cahaya oleh tumbuhan terlihat dari kemampuannya tumbuh pada intensitas cahaya rendah. Hal tersebut biasanya ditunjukan oleh titik kompensasi cahaya (TKC) Anakan menunjukkan efisiensi terhadap pemanfaatan cahaya yang jatuh pada lantai hutan, seperti penelitian Rostiwati (2005) menunjukkan TKC anakan 10,5 $\mu \mathrm{mol} \mathrm{m}^{-2} \mathrm{~s}^{-1}$; TKC pancang 35 $\mu \mathrm{mol} \mathrm{m}{ }^{-2} \mathrm{~s}^{-1}$ jenis Lithocarpus celebicus, Nilai tersebut menunjukkan bahwa anakan masih dapat beradaptasi pada intensitas cahaya rendah. Hal ini terkait juga dengan sifat toleransi suatu jenis tanaman, pada tanaman yang tahan naungan (toleran) titik kompensasi cahaya lebih rendah dibanding dengan jenis tanaman dengan sifat intoleran (Daniel et al., 1979). Ulin termasuk jenis tanaman yang semitoleran sehingga kondisi yang terjadi dengan intensitas cahaya yang terlalu tinggi akan memberikan dampak pada terganggunya pertumbuhan tanaman karena energy yang dikeluarkan untuk respirasi lebih tinggi dibandingkan energy yang dihasilkan dari fotosintresis.

Keragaman genetik dalam populasi ulin di Kalimantan juga masih cukup tinggi rata-rata sebesar 0,379 dan 0,356 (Widyatmoko, 2006). Pertumbuhan empat provenans ulin asal Kalimantan (Nanga Tayap Kalbar, Sumber Barito Kalteng, Sepaku Kaltim, Seruyan Hulu Kalteng) di Bondowoso Jawa Timur menunjukkan variasi pertumbuhan tinggi dan diameter yang berbeda sangat nyata pada pengukuran umur 6 bulan, 12 bulan dan18 bulan (Hakim, 2008). Peningkatan pertumbuhan diameter terbaik berasal dari populasi Bangka-Belitung dibandingkan dengan asal populasi Jambi dan Sumatera Selatan karena didukung oleh ukuran biji yang relatif lebih besar dan kematangan yang baik secara fisiologis. Oleh karena menurut Hartman dan Kester (1975), ukuran benih yang lebih besar mempunyai kandungan makanan yang lebih banyak sehingga dapat memacu embrio untuk tumbuh lebih cepat.

\section{KESIMPULAN}

\section{A. Kesimpulan}

1. Ulin (Eusideroxylon zwageri T. et B.) membutuhkan naungan yang optimum untuk pertumbuhan awalnya sebesar $81,05 \%$ dengan daya hidup sebesar $54,33 \%$.

2. Perlakuan asal benih memberikan pengaruh nyata terhadap pertumbuhan tinggi dan berpengaruh tidak nyata terhadap pertumbuhan diameter dan daya hidup tanaman ulin umur 1 tahun.

3. Asal benih ulin dari Belitung Timur memberikan pertumbuhan tinggi dan diameter terbaik masing-masing sebesar $47,47 \mathrm{~cm}$ dan $0,67 \mathrm{~cm}$ pada umur satu tahun.

\section{B. Saran}

1. Perlu dilakukan riset lanjutan mengenai lama waktu ulin membutuhkan naungan, dikarenakan karakteristik ulin yang bersifat semi toleran.

2. Dalam kaitannya dengan konservasi ex-situ ulin, perlu dilakukan eksplorasi menyeluruh terhadap sebaran alaminya. Benih dari semua tegakan dicampur secara merata dan dimapankan dalam suatu tegakan konservasi. 


\section{UCAPAN TERIMA KASIH}

Penulis menyampaikan terima kasih kepada PT Musi Hutan Persada Wilayah 1 Desa Suban Jeriji atas ijin penggunaan lahan untuk areal plot penelitian.

\section{DAFTAR PUSTAKA}

Abidin, A.Z. 2006. Selamatkan Kayu Bulian dari Kepunahan. www.kompas.com. Diakses tanggal 7 Januari 2008.

Badan Planologi Kehutanan. 2007. Laju deforestasi di Indonesia. Nomor: S.297/VIIPUSIN/2007.

Daniel, T.W., J.A. Helms dan F.S. Baker. 1979. Principles of Silviculture. Second edition. Mc Graw Hill Book Company. New York St Lauis. San Francisco. Auckland.

Erwandi. 2007. Kayu Khas Jambi punah. www.kompas.com. Diakses tanggal 7 Januari 2008.

Hakim, L. 2008. Variasi Pertumbuhan Empat Provenans Ulin Kalimantan. Jurnal Penelitian Hutan Tanaman 5 (2): 091-097.

Hardiyanto, E.B. 2007. Pemuliaan Pohon Lanjut. Handout. Fakultas Kehutanan Universitas Gadjah Mada. Yogyakarta (Tidak dipublikasikan).

Hartmann, H.T. dan D.E. Kester. 1975. Plant Propagation, Principles, and Practices. Prentise Hall, New Jersey.

Irawan, I. dan F. Gruber. 2002. Morphological Variability of Ironwood (Eusideroxylon zwageri T. et B.) in Natural Forest. The $3^{\text {rd }}$ International Symposium-cum-Workshop. The Southeast Asia Germany Alumni Network. Hanoi-Vietnam.

Irawan, I. dan F. Gruber. 2003. A Study on Tree Diversity in Association with Variability of Ironwood (Eusideroxylon zwageri T. et B.) in Jambi Indonesia. Technological and Institutional Innovations for Sustainable Rural Development. Georg-AugustUniversity Goettingen.

IUCN. 2000. Eusideroxylon zwageri. 2000 IUCN red list of threatened species.
Kramer, P. J. Dan T. T. Kozlowski. 1979. Physiology of Woody Plants. Academic Press. New York. San Francisco. London.

Marjenah. 2001. Pengaruh Perbedaan Naungan di Persemaian terhadap Pertumbuhan dan Respon Morfologi Dua Jenis Semai Meranti. Jurnal Ilmiah Kehutanan "Rimba Kali-mantan" Vol. 6 Nomor 2. Samarinda, Kalimantan Timur.

Masano. dan R. M. Omon. 1983. Observation on Natural Regeneration Eusideroxylon zwageri $T$. et $B$. in Senami Forest Complex, Jambi. Laporan Balai Penelitian Hutan, Bogor. (Tidak dipublikasikan).

Nugroho, A.W., F. Azwar, Junaidah dan J. Muara. 2006. Laporan Penelitian Teknik Silvikultur Ulin (Eusideroxylon zwagery T. et B). Balai Penelitian dan Pengembangan Hutan Tanaman Palembang (Tidak dipublikasikan).

Nurdin, Z. 2003. Kayu Bulian, Tebang Terus, Terus Tebang. www.kompas.com. Diakses tanggal 7 Januari 2008.

Rostiwati, T. 2005. Mekanisme Adaptasi Lithocarpus celebicus (Miq.) Rehd terhadap Naungan pada Tegakan Hutan Alam di Taman Nasional Lore Lindu, Sulawesi Tengah. Disertasi. Institut Pertanian Bogor, Bogor.

Samhadi, S.H. 2007. Hutan Dihancurkan, Bencana Didapat. Kompas: 13 Januari 2007.

Soerianegara, I. dan R.H.M.J. Lemmens (eds.). 1993. Plant Resources of South East Asia, Timber Trees: Major Commercial Timbers, PROSEA Vol, 5 (1): 1-610. Pudoc Scientific Publishers, Wageningen.

Widyastuti, S.M., Sumardi dan Harjono, 2005. Patologi Hutan. Cetakan pertama. Gadjah Mada University Press. Yogyakarta.

Widyatmoko, A.Y.P.B.C. 2006. Strategi Konservasi Ulin berdasarkan Informasi Keragaman Genetik. Prosiding Workshop Sehari. Peran Litbang dalam Pelestarian Ulin. Pusat Penelitian dan Pengembangan Hutan Tanaman. 